\title{
Nearshore and offshore wind development: Costs and competitive advantage exemplified by nearshore wind in Denmark
}

\author{
Klinge Jacobsen, Henrik; Hevia Koch, Pablo Alejandro; Wolter, Christoph
}

\section{Published in:}

Energy for Sustainable Development

Link to article, DOI:

10.1016/j.esd.2019.03.006

Publication date:

2019

Document Version

Peer reviewed version

Link back to DTU Orbit

Citation (APA):

Klinge Jacobsen, H., Hevia Koch, P. A., \& Wolter, C. (2019). Nearshore and offshore wind development: Costs and competitive advantage exemplified by nearshore wind in Denmark. Energy for Sustainable Development, 50, 91-100. https://doi.org/10.1016/j.esd.2019.03.006

\section{General rights}

Copyright and moral rights for the publications made accessible in the public portal are retained by the authors and/or other copyright owners and it is a condition of accessing publications that users recognise and abide by the legal requirements associated with these rights.

- Users may download and print one copy of any publication from the public portal for the purpose of private study or research.

- You may not further distribute the material or use it for any profit-making activity or commercial gain

- You may freely distribute the URL identifying the publication in the public portal 


\title{
Nearshore and offshore wind development: Costs and competitive advantage exemplified by nearshore wind in Denmark
}

\author{
Henrik Klinge Jacobsen, Pablo Hevia-Koch and Christoph Wolter \\ Technical University of Denmark, DTU Management, Energy Economics and Regulation
}

Preprint: Energy for Sustainable Development, 50, p 91-100

\begin{abstract}
Nearshore wind development has been seen as the cost reducing option that could shrink the cost gap between onshore and offshore development. The cost advantage is linked to more shallow water and shorter connection to shore even avoiding an offshore substation. Public tendering for offshore wind in Denmark has opened up for near-shore wind turbine farms as an alternative for lowering the cost of new offshore wind development. Whether these proposed near-shore locations will manage to significantly lower costs is not clear. The tenders have resulted in bids that are at comparable levels for the nearshore and the further offshore wind farms. We compare the cost drivers and possible cost differentials with preferences for locating wind farms further away from the coast. The main cost driver is water depth and in the Danish case water depth is increasing slowly or is not even correlated with the distance from shore. Therefore the willingness to pay for moving turbines away from the coast may be sufficiently high to balance the increased cost. The actual comparison of costs and willingness to pay must be carried out for the specific case with cost characteristics and willingness to pay by the affected population.
\end{abstract}

Keywords: offshore wind; cost drivers; preferences; nearshore

\section{Introduction}

Wind energy is among the cheapest renewable technology options when ambitious targets for renewable energy have to be met. On-shore wind is competitive for many countries when compared to conventional generation, but barriers and public resistance slow down the development in some countries. Currently there exist high expectations for the development of wind energy, particularly in Europe, out of which offshore wind turbine developments will be central as tools to achieve current energy targets. Offshore wind development is still more costly but because land for onshore development is scarce in many countries, offshore wind sites have also been developed especially in Europe. In 2017 Denmark had 4228 MW onshore and 1292 MW offshore capacity of wind (Danish Energy Agency, 2017). Costs for offshore wind varies a lot depending on specific location, water depth and distance as well as actual technology applied. Offshore wind costs have recently declined substantially reducing the span between onshore and offshore wind costs, but offshore wind will continue to have higher costs than onshore wind. One consequence of increased focus on offshore projects with a higher cost level is that the expansion of wind generation in general could slowed down caused by increased financing requirements. Financing of the necessary support has become more of a public issue with electricity consumers, especially industry, increasingly pressuring to be exempted from contributing to financing via public service obligations. However, further cost reductions are expected (Wiser et al., 2016a), (Wiser et al., 2016b) and especially the option of using more shallow waters closer to shore is considered as a way to reduce costs of offshore wind. The choice between nearshore and (far)-offshore is particularly relevant, both because of increased public resistance due to visual disamenities produced by nearshore projects, and because of the potential cost reduction benefits attained by building wind farms closer to the shore.

In Denmark this option has also been considered and some nearshore sites were already included in tenders in 2017. For Denmark the nearshore option is very relevant since the shoreline including many islands is very long relative to the size of the country and therefore constitutes a sizeable potential for wind development. The smaller possible size of the nearshore projects may facilitate more competition, especially from domestic 
developers as has been an argument in Denmark, but it may also lead to less participation from the global offshore developers that exploit economies of scale in wind farms. If dominated by the first, this produces a more competitive environment for the bidding process of the smaller nearshore projects that may allow new entrants into the offshore development and eventually push for lower prices. Also in Greece the potential for nearshore siting is considered an interesting option (Mytilinou, Kolios, \& Lorenzo, 2017).

This paper investigates the cost characteristics of nearshore wind and the specific cost drivers that are expected to make it cheaper than further offshore wind. We define nearshore wind as turbines that are up to $15 \mathrm{~km}$ off the coast. Based on this need, an analysis of the differences between costs and cost drivers for both offshore and nearshore is needed, as well as an exploration towards other possible factors that might affect the relative advantage of nearshore compared to offshore projects. We compare Danish nearshore sites with cost characteristics of further ashore wind in Denmark. Costs for nearshore are expected to be lower due to lower connection costs, foundation, and to some extent, operation and maintenance. These lower costs must be balanced by the less favourable wind conditions and the costs associated with public resistance. Carefully selecting the nearshore sites with low resistance and low cost characteristics can hopefully reduce the cost of expanding the offshore wind capacity in Denmark where there is a considerable amount of coast line compared to the area of the country. Here, the focus is on trying to determine the cost differential for wind farms located at different distances from the coast in comparison to the typical cost for further offshore wind farms in DK. The most important cost driver is water depth and in this respect Denmark is probably not representative of offshore conditions in other regions. There may still be available shallow sites in Denmark that are further from the coast, and these may be substantially preferred to the nearshore sites.

The paper is organised with a first section describing the cost characteristics of offshore wind and the main variables and assumptions included in the calculation of Levelised Cost of Energy (LCOE). The next section examines the characteristics of offshore wind in Denmark. The following section evaluates the cost advantage of nearshore wind with Danish characteristics. The last section discusses and compares the cost advantage with public preferences for shifting wind development further offshore. A final section concludes on the findings and implications for Danish wind expansion.

\section{Comparing costs of energy using Levelised Cost of Energy}

The Levelised Cost of Energy (LCOE) is a commonly used measure to compare costs of energy technologies. It focuses on the cost of supplying energy (electricity) and do not include the varying revenues from generation depending on fluctuating supply at different hours of the day and year. We are focusing on comparing nearshore and offshore wind development in Denmark including different sites that may imply some variation in wind conditions and specific short term generation profile, but the difference in profile and thereby value per generated unit is not expected to be significant, such as can be the case when comparing across more fundamentally different technologies and power markets/countries.

There may be minor differences in the lifetime of turbines and the variability of the generation, but they are generally small within the wind technology, and therefore the LCOE is a reasonable measure for the comparison here.

\subsection{LCOE assessment for power generators}

Calculating the LCOE is a tool not only used for assessing the economic performance of offshore wind energy but is utilised throughout the industry to evaluate the cost-effectiveness of different forms of power generation technologies and to compare them with each other. In that way, a comparison also between conventional and renewable power generators can be made even though these technologies can differ significantly in their cost structure. While conventional generators usually face a high share of their total lifetime costs with variable costs such as expenses for fuel, for most renewable energy sources a significant part constitute the investment costs occurring at the beginning of the investment projects, particularly for those technologies where no cost for fuel accrues. The LCOE thus is, on the surface, a straightforward measure for the investigation scope of an energy market as a whole to examine the competitiveness of different energy technologies. LCOE represents the cost over the lifetime of an investment relative to the expected energy production. This is usually an average annual production based on expected number of hours of generation and technical characteristics. It also includes the time value of money by discounting the cost over the lifetime. While it can be challenging to identify the correct 
discount factor to be used for calculating LCOE when comparing different technologies, in the case of comparing offshore with nearshore wind, this is not a difficulty, and therefore LCOE is a good tool to use.

While comparing the LCOE for different power generation systems within a specific market is a simple indicator to identify which technology produces electricity at the lowest cost, it is not so simple to compare LCOE analyses across studies for different markets or countries even for the same power generation technology without considering cost allocation principles and regulation. Countries use various regulations and guidelines of how to assign cost elements to generation or grid and sometimes costs are indirectly affected by national support variations.

\subsection{LCOE comparison of wind using national characteristics/differences}

Great care has to be taken when utilising LCOE measures for comparing different projects, mainly when the projects compared are sited in different countries. While the units for LCOE are the same, there is no standard definition regarding which costs are included in the calculation of this measure.

(Visser \& Held, 2014) studies different assessments of LCOE in the Netherlands, United Kingdom, Germany and Spain and finds out that besides from CAPEX and OPEX, which are considered in every analysis, residual costs such as decommissioning, grid balancing, and cost of market integration are not integrated into the LCOE analyses of every country. Furthermore, grid connection costs are frequently ignored, since very few countries (such as the UK) include these costs in the scope of the project and the LCOE assessment. A comparison of the importance of connection cost in EU can be found in (Auer, 2006). These kinds of differences will, therefore, affect the LCOE estimates for different projects, and make comparison difficult.

The height of balancing costs differs in countries due to the respective production portfolio and the flexibility of and the transmission with the surrounding electricity system. Despite a high share of energy production stemming from wind power, the average balancing costs for wind power producers in Denmark is estimated at 2 EUR/MWh, which is in the lower range of the wind energy balancing costs in Europe, due to the interconnection with other electricity markets and most notably the flexible hydropower plants in the Norwegian power system (Danish Energy Agency, 2015b). The balancing costs for wind power producers in the United Kingdom in contrast are estimated at $3 \mathrm{EUR} / \mathrm{MWh}$ at the upper range of average wind energy balancing costs in Europe, likely due to the poorer interconnection to the electricity grid of continental Europe (EWEA, 2015), or differences in the design of the balancing market, in regard to regulating power and frequency restoration reserves.

Another highly sensitive parameter for the LCOE calculation is the choice of the discount rate as stated in (Visser \& Held, 2014), which usually varies throughout different countries. This procedure is due to a different perception of risk and various estimations of alternatives for public investments in specific national markets. The characteristic values of discount rates that are suggested by governmental bodies can differ significantly between countries, for example between the United Kingdom and Denmark. While the British government suggests a discount rate of $10 \%$ (nominal) for all projects to be able to have a neutral national comparison of projects in terms of financing and risk assessment (DECC (Department of Energy \& Climate Change), 2013), Denmark suggests a discount rate of 4\% (real)(Danish Energy Agency, 2013) due to their socio-economic focus of project evaluation. As a consequence, Danish LCOE assessments of offshore wind energy usually are characterised by a tendency of having lower levelised costs than British evaluations, due to the lower discount rate used in Denmark. For the investment calculation and decision the NPV is the usual measure to compare and LCOE is related but less important (González, Rodríguez, Mora, Burgos Payán, \& Santos, 2011). Danish LCOE's for existing wind farms are also lower than in most other countries due to shallow water and relatively good wind conditions for the already built wind farms. This is off-course a limited resource as substantial offshore wind development in Denmark may have to use deeper water.

From an investor's point of view, the LCOE assessment is also subject to other limitations. Since the projection of energy generation, especially for fluctuating renewable energy sources, is prone to uncertainty, an LCOE analysis does not always express the full profitability of a project for the investor, or it contrarily underestimates the LCOE by overestimating energy production. One particular element to consider is also curtailment of generation due to market balancing issues or cabling capacity constraints(Klinge Jacobsen \& Schroder, 2012). Moreover, monetary profits over the lifetime of the asset are not considered when looking exclusively at the LCOE, so that support schemes and electricity market prices are not integrated into the analysis. Similarly, a particular market price structure may compensate for the occurring costs with the result that particular 
technologies can be more profitable although they are constituted by a higher LCOE. As (Joskow, 2011) argues, a comparison of LCOE for different technologies implies to treat the produced electricity as a uniform product which is always or in average priced equally. Yet due to market price fluctuations or different capacity factors and thus operating times the revenue stream can affect the actual profitability of the asset considerably. In markets with substantial wind shares the average market value of generation will be less than in markets with little wind even if the average market price is at comparable levels.

Looking at some of the factors driving differences in LCOE for wind energy (Millborrow, 2016) illustrates the effect of wind condition combined with different investment costs. Figure 1 reproduce this comparison that illustrates higher cost level for offshore and also larger variation in costs depending on actual wind speed compared to onshore. This may suggest that nearshore should have a relatively large cost advantage to outweigh the likely less favourable wind conditions.

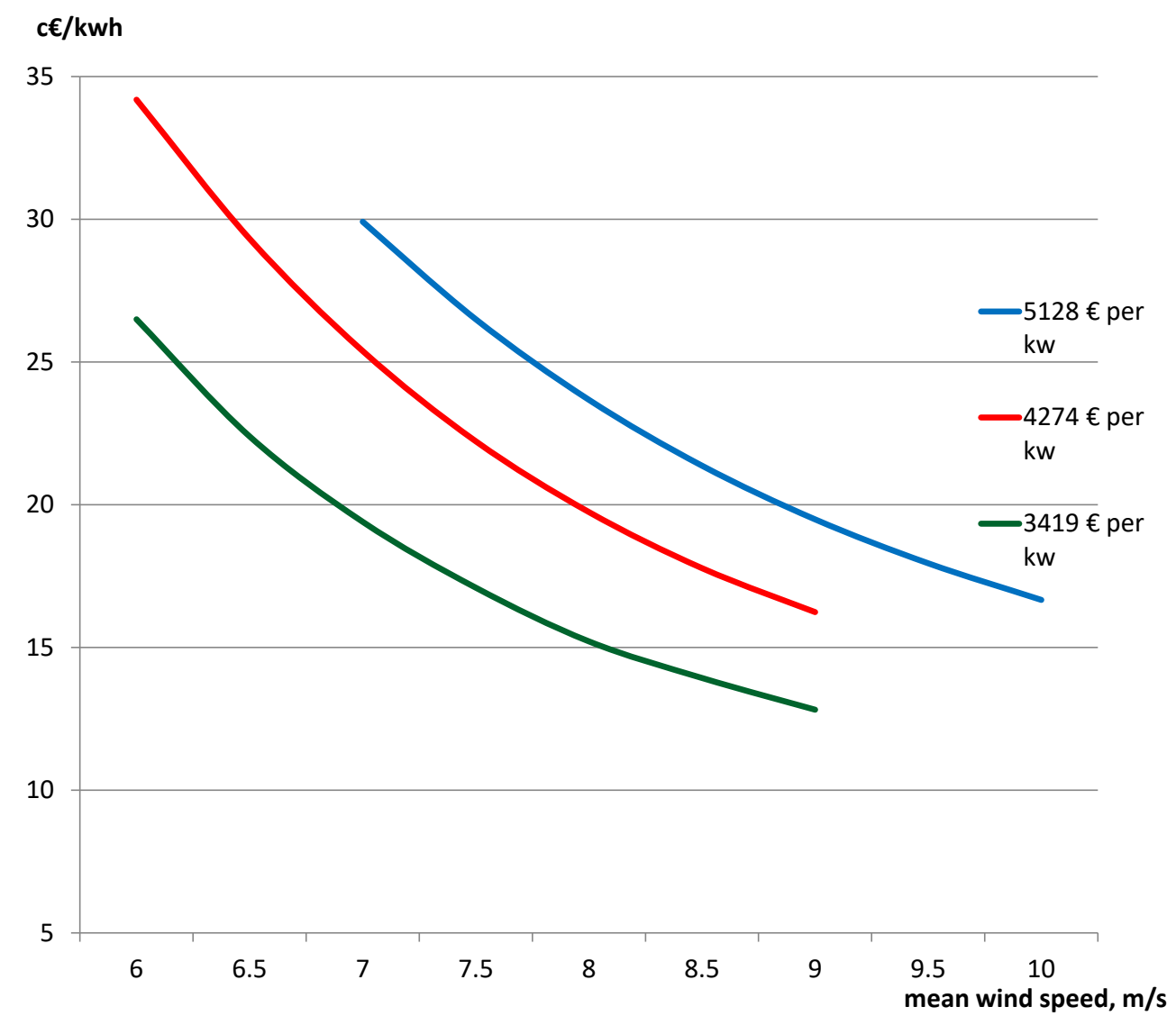

Figure 1: LCOE for offshore wind depending on capacity factor and investment costs. Based on (Millborrow, 2016)

In Figure 1 the sensitivity of LCOE to investment cost and wind speed is given for offshore wind. For offshore the absolute sensitivity of LCOE to wind speed is quite large and the specific siting of offshore wind farms is therefore critical for bringing LCOE down. Wind conditions at nearshore and further offshore sites differ and for specific sites moving turbines closer to shore result in lower annual energy production reducing the positive effect on LCOE from lower investment costs. This naturally depends on the characteristics of the shoreline, but also whether the considered nearshore sites are in the same areas as the far offshore.

To compare with international estimates of the variation in LCOE depending on capacity factor and discount rate (Wiser et al., 2011, fig. 7.23)) reports a LCOE of 5 USD cents/kWh with low investment cost at a 35\% capacity factor is given. The right panel in their figure shows a reduction of LCOE by $1.5-2$ USD cents $/ \mathrm{kWh}$ by with a discount rate that is $3 \%$ compared to $7 \%$. This sensitivity is also important remembering the $4 \%$ discount rate used in many Danish studies.

\section{Investment costs for offshore}


Commonly the total investment costs are broken down into various cost components. By presenting different shares for the cost components, different projects can be compared with each other in more detail, since for instance the effects of the geographical characteristics of the offshore wind farms on the investment can be revealed. The comparison of different wind farms, however, in general, is more accurate for projects with similar commissioning time, similar geographical characteristics or comparable technical characteristics as for instance the type of turbines or the installed capacity.

Table 1 presents estimates of cost shares for onshore and offshore wind farms found in the literature for different publication years. The inclusion of components differs when looking at the different cost breakdowns, making it challenging to allocate different costs where they actually arise. Mainly, the installation cost is sometimes not reflected independently in presented cost breakdowns, leading to a distortion of the remaining cost component shares. Also, the cost for electrical components is sometimes not addressed in cost breakdowns, due to the fact that these components are not always included in the project scope of the wind farm investor, but are constructed and invested by other entities. The problem of different investment cost splits throughout the literature has been mentioned by (Voormolen, Junginger, \& van Sark, 2015). The cost shares for nearshore wind farms will probably be most similar to the offshore wind farms compared to onshore wind, with a higher turbine share and slightly lower shares for electrical/connection costs and foundation. The cost share for turbines will depend on the actual size of turbines and this choice may vary more for nearshore than far offshore, due to larger variation in wind conditions and regulatory constraints on turbine size (height). The share of foundations will be higher for far offshore as this component depends largely on depth and foundation technology.

\begin{tabular}{lcccc}
\hline & $\begin{array}{c}\text { IRENA (2012) } \\
\text { Onshore }\end{array}$ & $\begin{array}{c}\text { IRENA } \\
\text { (2012) } \\
\text { Offshore }\end{array}$ & $\begin{array}{c}\text { EWEA (2009) } \\
\text { Offshore }\end{array}$ & $\begin{array}{c}\text { Kitzing \& Morthorst } \\
\text { (2015) Offshore }\end{array}$ \\
\hline Turbine & $65-84 \%$ & $44 \%$ & $49 \%$ & $40 \%-60 \%$ \\
Foundation & & $16 \%$ & $21 \%$ & $20 \%$ \\
$\begin{array}{l}\text { Electrical/connection } \\
\begin{array}{l}\text { Installation/ } \\
\text { Construction }\end{array}\end{array}$ & $9-14 \%$ & $17 \%$ & $21 \%$ & $25 \%$ \\
Other & $4-16 \%$ & $13 \%$ & & \\
\hline
\end{tabular}

Table 1: Onshore and offshore wind farm cost shares from the literature

\section{Operation and maintenance costs for offshore}

Operation and Maintenance costs (O\&M) or OPEX are expressed within the annual costs after commissioning of the farm and tend to increase over the farm's lifetime. The O\&M costs are either expressed as variable cost per MWh generated or as a fixed cost per MW installed capacity, also lacking a standard approach for their definition. This is due to the fact that different parts of OPEX are variable cost, such as repair costs and to a certain extent spare parts and maintenance (which are likely to be related to the production level) and other parts are fixed costs, such as insurance costs, administration and regular maintenance (which are likely to be related to the fixed installed capacity. According to (Energinet.dk \& Danish Energy Agency, 2017), for 2015 fixed O\&M costs are 57,300 EUR/MW/year, while the variable costs are 4.3 EUR/MWh.

One can combine the variable cost depending on the energy produced and the residual fixed cost to obtain the total OPEX cost. For offshore wind, the variable part of the OPEX is estimated to be half of the total OPEX (Voormolen et al., 2015). In general, information regarding OPEX is hard to obtain. In the literature it is estimated to be in a range of 15-49 EUR/MWh (Kitzing \& Morthorst, 2015),(Morthorst \& Kitzing, 2016) in variable terms and $2.2 \%-4 \%$ in fixed terms as share of CAPEX (DECC (Department of Energy \& Climate Change), 2013; Heptonstall, Gross, Greenacre, \& Cockerill, 2012; Prässler \& Schaechtele, 2012). Over the total lifetime of the farm, the OPEX can encompass 25-30\% of the total project cost (Kitzing \& Morthorst, 2015).

Considering the aforementioned geographical cost drivers, mostly the distance to the nearest maintenance port directly affects the OPEX, due to the cost connected to the travel time of the maintenance vessel and potentially rougher weather conditions at sites further offshore, which constrain the operation time on site. After assessing the total cost of a wind farm project, the LCOE can be estimated when predicting the energy generation of the farm over the total lifetime. Foer nearshore wind this may be a benefit as the distance is expected to be less to 
the maintenance port. For larger offshore wind projects maintenance platforms servicing more farms will reduce this cost differential between nearshore and offshore wind. If further offshore wind is located only $15-25 \mathrm{~km}$ from the coast as in Denmark the difference in distance to maintenance port is also small.

\section{Offshore and nearshore wind costs for Denmark}

\subsection{Current status of offshore wind energy in Denmark.}

Offshore wind energy has been growing in Denmark in a sustained manner, since the first offshore wind turbine park, Vindeby, was erected in 1991. As of 2017, there are 12 offshore wind turbine farms in Denmark, since the decommissioning of the Vindeby park, with a total installed capacity of 1271 MW (Danish Energy Agency, 2015a). A list of existing offshore wind energy farms and some necessary information is found in Table 2.

\begin{tabular}{lccccc}
\hline Wind Farm & $\begin{array}{c}\text { Lifetime } \\
\text { Capacity } \\
\text { Factor }\end{array}$ & $\begin{array}{c}\text { Age } \\
\text { [Years] }\end{array}$ & $\begin{array}{c}\text { Installed } \\
\text { Capacity } \\
\text { [MW] }\end{array}$ & $\begin{array}{c}\text { Depth } \\
\text { [m] }\end{array}$ & $\begin{array}{c}\text { Distance } \\
\text { to shore } \\
\text { [km] }\end{array}$ \\
\hline Anholt 1 & $49 \%$ & 4 & 400 & 17 & 18 \\
Avedøre Holme & $38 \%$ & 7 & 11 & 1 & 0 \\
Frederikshavn & $31 \%$ & 14 & 8 & 4 & 3 \\
Horns Rev I & $42 \%$ & 15 & 160 & 10 & 17 \\
Horns Rev II & $48 \%$ & 8 & 209 & 13 & 30 \\
Middelgrunden & $25 \%$ & 17 & 40 & 4 & 5 \\
Nysted (Rødsand) I & $37 \%$ & 14 & 166 & 9 & 9 \\
Nysted (Rødsand) II & $43 \%$ & 7 & 207 & 1 & 0 \\
Rønland I & $45 \%$ & 15 & 17 & 12 & 4 \\
Samsø & $39 \%$ & 15 & 23 & 11 & 11 \\
Sprogø & $34 \%$ & 8 & 21 & 5 & 6 \\
Tunø Knob & $30 \%$ & 22 & 5 & 3 & 2 \\
Vindeby (closed) & 22\% & 26 & 5 & $\mathbf{7 . 5}$ & $\mathbf{8 . 9}$ \\
\hline Total & $\mathbf{4 1 . 4 \% ~ ( a v g . ) ~}$ & $\mathbf{1 3 . 2}$ (avg.) & $\mathbf{1 2 7 1}$ & & 9 \\
\hline
\end{tabular}

Table 2 Offshore wind farms in Denmark

It is expected for offshore wind to keep expanding in future years, as part of the strategy regarding renewable energy goals. Currently, there are eight projects under development or assigned for environmental impact assessment with a total nameplate capacity of up to $2.2 \mathrm{GW}$ : Horns Rev 3, Kriegers Flak, Vesterhav Nord og Syd, Nissum Bredning, Omø Syd, Jammerland Bugt, Mejl Flak, and Lillebcelt Syd. Horn Rev3 will be completed in 2019, the next two after 2020. Only Vesterhav Nord and Syd are nearshore wind farms at a total capacity of 350MW. Furthermore, a number of areas for future tenders are being considered for the development of new offshore wind energy farms. Some of the areas are offshore locations close to the shore, which aim to lower the costs for installing and operating the wind turbines, as for example Sejerøbugten, Smålandsfarvandet and Sceby (Danish Energy Agency \& Energinet.dk, 2013). With the new energy agreement in June 2018 additionally 800 MW is planned for commissioning before 2027 and additional capacity foreseen before 2030.

\subsection{Costs for Offshore wind in Denmark}

The major factor resulting in higher offshore cost in Denmark in comparison with onshore wind is the significantly higher capital cost. Costs will vary depending on the location, due to water depth, distance to coast, sea conditions, and more (Kitzing \& Morthorst, 2015). However, the variation in Denmark is expected to be lees due to less variation in water depth, distance to shore and less variation in offshore wind conditions.

Denmark is probably positioned in the low end of the international average cost for off-shore wind development. This is evident from a comparison of levelised cost of offshore wind energy (LCOE) including projections from major agencies and associations in the wind sector. In Figure 2 we compare cost levels across the projections of several reports. The wideness of the cost range for each source reflects both the uncertainty in technology 
development and the underlying difference in cost driving characteristics within the area examined (country/region). The Danish Energy Agency numbers and forecasts are at the lowest level compared to the levels provided by other sources. Therefore, we must expect that the cost benefits from moving wind farms from average off-shore to nearshore locations in Denmark is less than for most other countries (in line with the generally shallow seabed conditions in Denmark).

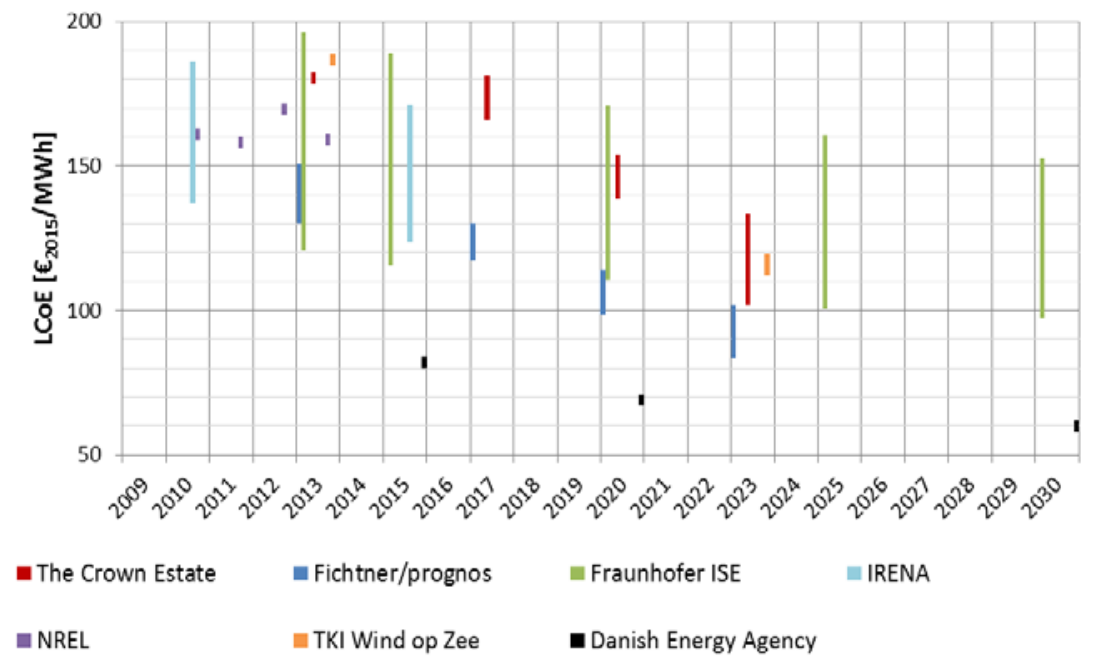

Figure 2 Comparison of levelised cost estimates and ranges for offshore wind in the literature

The estimates in Figure 2 are based on the following sources: (Fichtner/prognos, 2013; Fraunhofer ISE, 2013; International Renewable Energy Agency, 2012; The Crown Estate, 2012; TKI Wind op Zee, 2015).

The cost projections in Figure 2 assume a considerable cost reduction over time, but it is not clear whether this is expected to cover mainly the far off-shore projects in deeper waters. If compared to the development in basic investment costs as given in (Gonzalez-Rodriguez, 2017)(fig 1) the historical development is in contrast to these expectations. From 2000 up to 2015 the investment costs per MW capacity increased, but this may have been partly due to wind farms being developed at larger depth, increasing prices of steel and limited competition in the offshore segment. The expected cost reductions in offshore have been studied internationally examining learning, time and scaling effects as in (Van der Zwaan, Rivera-Tinoco, Lensink, \& van den Oosterkamp, 2012). If cost decreases are expected to be dominated by foundation technology improvement and installation cost reductions, then the nearshore projects may benefit less and thus the relative cost advantage of nearshore wind will decline over time.

\subsection{The Danish offshore LCOE}

We want to compare costs for nearshore and further offshore wind energy in Denmark. Among the factors that affect the costs for different locations, we could consider four general categories: technical costs that will vary with water depth and distance to shore, distance to service port, impact associated with availability and profiles of wind in the area, and costs associated with the social impact produced by the wind farm. In (Hevia-Koch \& Jacobsen, 2019) onshore basic costs were combined with costs to secure local acceptance for onshore development relative to offshore.

From a technical perspective, as different wind sites are exploited, two main variables will affect these previous costs: distance to shore, and water depth. Technical costs will be affected by both variables: as water depth increases it becomes more expensive to install the wind turbines, and at specific water depths, more expensive foundation technologies have to be used. Similarly, as the distance to shore increases, O\&M becomes more expensive and the costs for cabling during installation, as well as the costs related to port availability and installation time increase as well. 
When looking at the prospect of future offshore wind energy expansion, we must account not only for the total existing potential in terms of areas with wind but also for the associated evolution of cost as this potential is exploited. As offshore wind energy grows, the first areas to be utilised will be those with lower costs, and therefore leaving for later exploitation high-cost areas. Even if we ignored the time dimension and associated technological changes, sites that are exploited earlier will still present lower costs, either due to being sites with better wind conditions, or with conditions that make investment costs lower (such as water depth).

The cost curve used for Denmark is based on data from the RESOLVE model, and presented in (Beurskens \& Hekkenberg, 2011) and (Hevia-Koch \& Jacobsen, 2019). The curve for offshore wind covers an offshore wind expansion potential of around $11 \mathrm{GW}$. LCOE levels range between $9 \mathrm{c} € / \mathrm{kWh}$ for small amounts of exploited potential, climbing steadily up to approximately $17 \mathrm{c} € / \mathrm{kWh}$ before spiking up to a final level of $19.9 \mathrm{c} € / \mathrm{kWh}$ for the full potential. This upwards sloping curve represents the increased costs of further exploiting wind sites, as discussed above. These estimates are consistent with several other studies finding prognosis of offshore wind LCOE (Fichtner/prognos, 2013; Fraunhofer ISE, 2013; IRENA, 2012; Mone, Hand, Maples, \& Smith, 2015; The Crown Estate, 2012; TKI Wind op Zee, 2015), a selection of which is shown in Figure 2.

Offshore wind cost have dropped significantly in Europe recently, and this is also exemplified by the Danish Kriegers Flak project with a bid of $4.9 \mathrm{c} € / \mathrm{kWh}$. This is lower than many previous expectations such as the one study we base our cost curve on (Beurskens \& Hekkenberg, 2011) and the average of those in Figure 2. For this reason, we adjust the cost curve such that the cost level is reduced (47\%) for the entire cost curve. This proportional reduction of cost can certainly be questioned but there are very limited observations to use in DK with the new lower cost level. The purpose here is entirely to demonstrate the level of cost for nearshore in comparison with cost levels for other offshore potential in DK and not to use it directly for calculation of cost differences. The adjusted cost curve following (Beurskens \& Hekkenberg, 2011) data are presented in Figure 3.

The adjusted cost curve represents offshore potential in Denmark, but only a limited amount of the potential is actually nearshore. Around $1000 \mathrm{MW}$ of the potential in the figure corresponds to nearshore locations and the cost level is close to the $6 \mathrm{c} € / \mathrm{kWh}$ expected for the Vesterhav Syd site that will be developed 2019-2021.

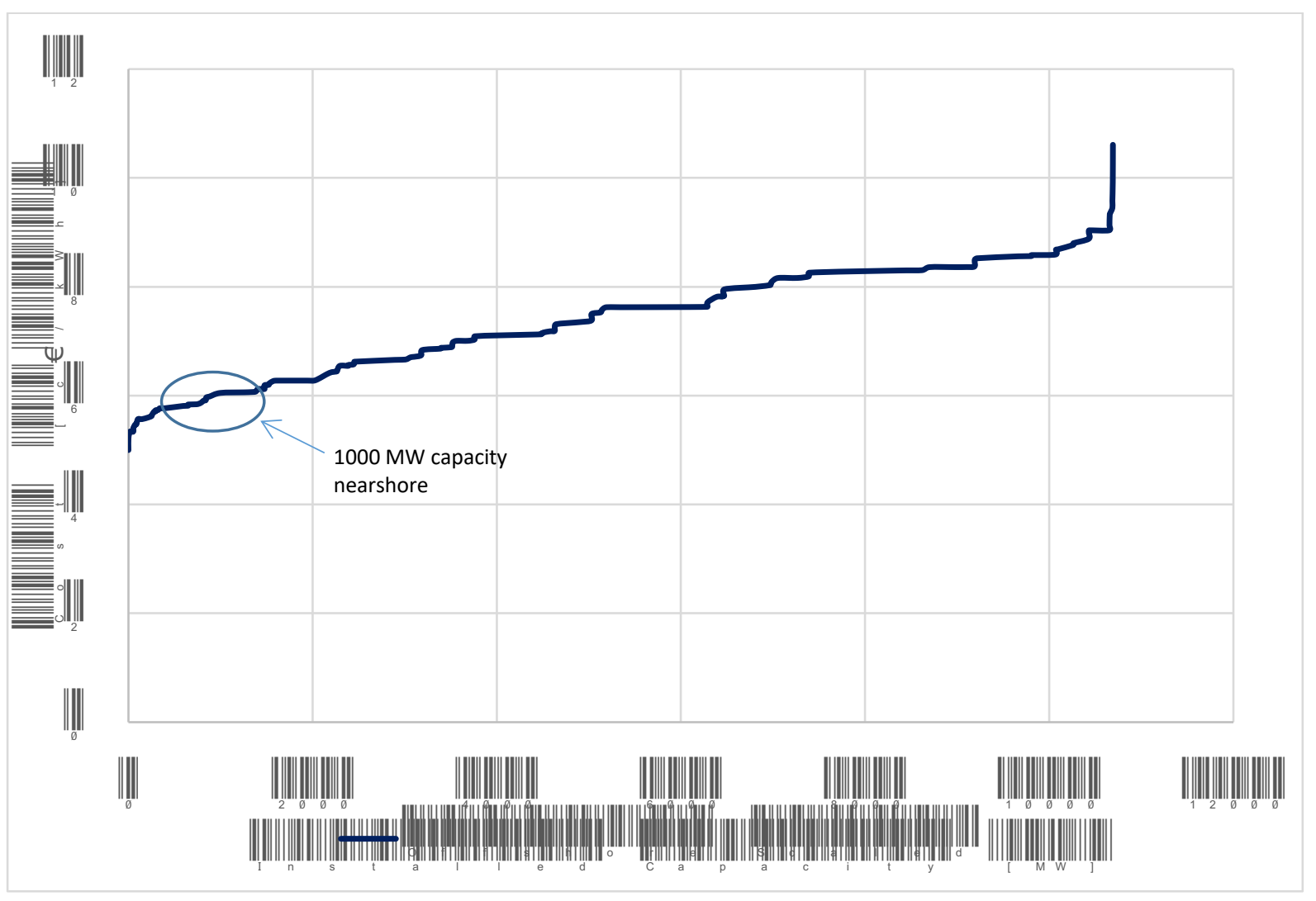

Figure 3: Offshore wind cost curve for Denmark adjusted from 2011 figures used in (Beurskens \& Hekkenberg, 2011) to level of Kriegers Flak (LCOE) 
The nearshore capacity in Figure 3 cannot be referred to a specific depth but following the curve it is clear that costs are lower than for the majority of the far offshore potential. This makes it highly relevant to investigate the cost differentials relative to the preferences for the people potentially affected by the nearshore turbines.

\section{Results for comparing costs of nearshore and further offshore development in Denmark}

\subsection{Cost differences in Denmark}

We define nearshore wind as turbines that are up to $15 \mathrm{~km}$ off the coast, which provide a lot of potential in Denmark that have a very long coastline. The distance is not the only important cost driver, but it is this parameter that is significant and related to both cost advantages for nearshore development and disadvantages arising from public preferences against close to shore wind turbines.

To quantify the potential cost advantages of nearshore, we use an international source (EEA, 2009) that provides scaling factors based on only distance to shore and water depth. We then recalculate and calibrate based on cost data from one specific Danish wind farm Rødsand II.

Table 3 provides scaling factors for costs based on only depth and distance from shore. The origin is $4 \mathrm{~km}$ from shore and a water depth of $15 \mathrm{~m}$. Nearshore costs are then represented by the first 5 columns up to $15 \mathrm{~km}$ from shore giving also factors for two additional distances in the last two columns. For the water depth the table exceeds what is basically realistic for Denmark. If keeping the distance down to max $15 \mathrm{~km}$ the depth will rarely be more than $25 \mathrm{~m}$. That means the least favourable cost characteristics in Denmark will probably be characterised by only 9\% higher cost than in the origin. With max $15 \mathrm{~km}$ from shore as the definition for nearshore we will not have to consider if an offshore substation will have to be build, which would probably be nearly as large a cost difference as the $9 \%$ in the table.

\begin{tabular}{|c|c|c|c|c|c|c|c|}
\hline $\begin{array}{c}\text { Water depth } \backslash \text { Distance } \\
\text { from shore }\end{array}$ & $4 \mathrm{~km}$ & $8 \mathrm{~km}$ & $10 \mathrm{~km}$ & $12 \mathrm{~km}$ & $15 \mathrm{~km}$ & $20 \mathrm{~km}$ & $25 \mathrm{~km}$ \\
\hline $5 m$ & & & & & & & \\
\hline $10 m$ & 0.967 & 0.974 & 0.978 & 0.982 & 0.988 & 0.998 & 1.008 \\
\hline $15 \mathrm{~m}$ & 1.000 & 1.008 & 1.012 & 1.016 & 1.022 & 1.033 & 1.043 \\
\hline $20 m$ & 1.034 & 1.042 & 1.046 & 1.050 & 1.056 & 1.067 & 1.078 \\
\hline $25 \mathrm{~m}$ & 1.067 & 1.075 & 1.080 & 1.084 & 1.090 & 1.102 & 1.113 \\
\hline $30 m$ & 1.124 & 1.133 & 1.137 & 1.141 & 1.148 & 1.160 & 1.172 \\
\hline $35 m$ & 1.237 & 1.247 & 1.252 & 1.257 & 1.264 & 1.277 & 1.290 \\
\hline
\end{tabular}

Source: Calculated based on EEA, 2009 (Table 6.4)

Table 3 Cost scaling factors used for DK comparison

To compare the (EEA, 2009) scaling factors with data for Denmark a simple regression for total levelised costs of 14 offshore wind farms based on depth and distance from shore is reported. We utilise information for distance to shore, water depth, and LCOE for Danish offshore wind farms from 1991 up to 2018, which is a long period of time considering the tremendous technology development. We don't account for that, but acknowledge that these factors (in particular age) in principle may be just as important for explaining different cost levels. To see the influence of distance to shore and water depth, we create three linear regression models that express LCOE as a function of distance to shore, water depth, and both. The results of two of the models are presented in Table 4 in Appendix A. The models indicate that the LCOE for Danish offshore wind farms cannot be explained by the distance to shore, (in-significant coefficient), but by the depth of the sea. This result can only be used very cautiously because of the limited number of observations and the omitted variables, but the result is in line with using a very modest cost increase for increasing distance to shore as is found in Table 3 and that is chosen here. 
The shares of cost components are different for near-shore and far offshore wind farms, but the cost drivers are basically the same. Connection cabling, as well as installation (and mostly foundations) represent a smaller cost share for nearshore wind, but due to the more varying local conditions for connection, the distance from shore is less important as cost driver compared to the depth. The sea depth and wind conditions are the main drivers, similar to far offshore, and the turbines/steel costs are providing similar cost impacts for the two categories.

In Figure 4 the cost curves for different distances and depth are illustrated with the Rødsand II wind farm as the reference sited at an approximate $10 \mathrm{~km}$ distance from shore and an average depth of $10 \mathrm{~m}$. Two other recent cost figures are also provided in the graph as points.

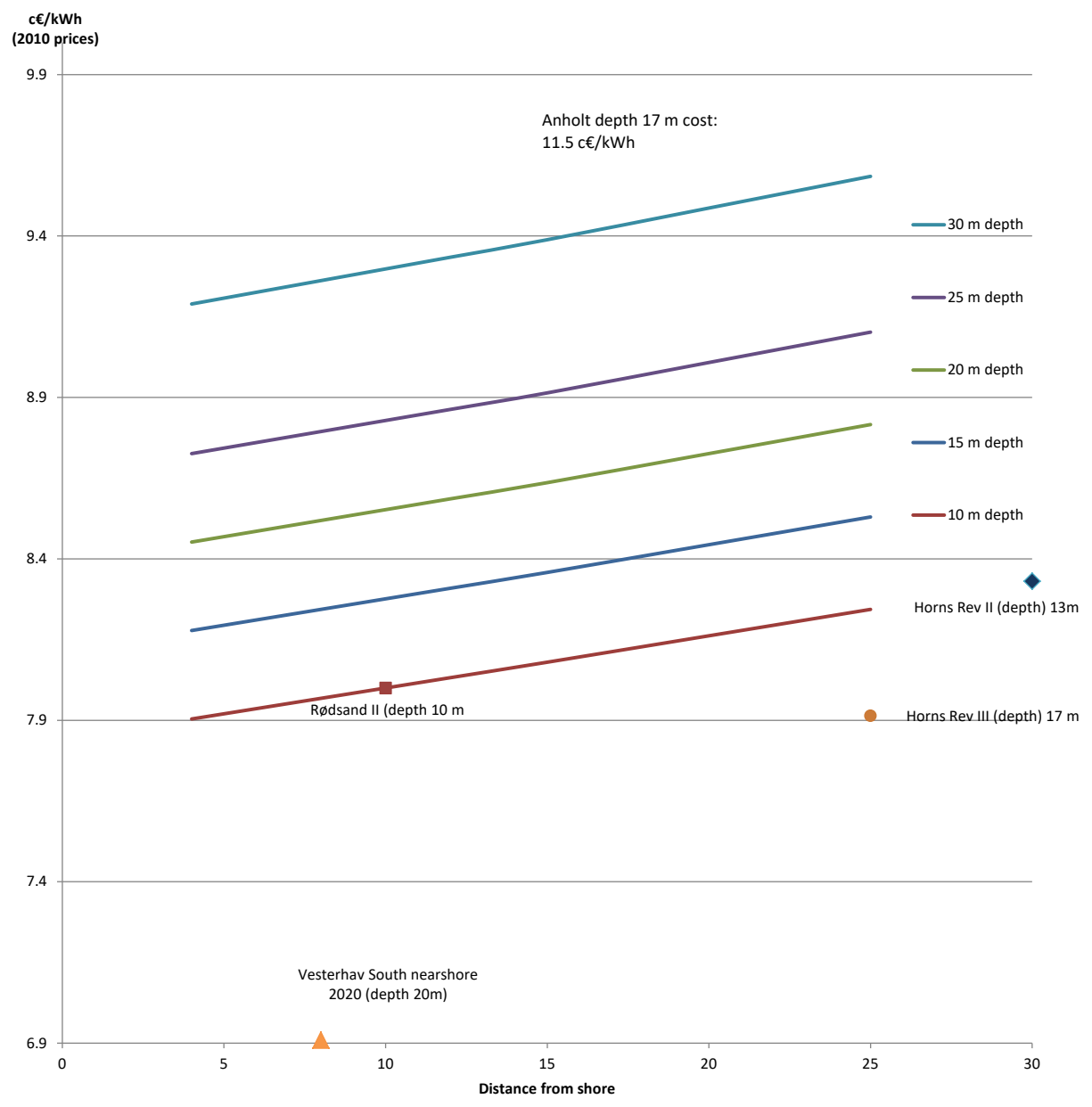

Figure 4 Illustration of cost relationship for DK with indicative benefit (adjusted to 2010 level based on Rødsand II and EEA scaling factors in Table 3)

The illustration for potential benefits in DK clearly shows that the main cost benefit will be achieved if it is possible to reduce the water depth by locating the wind farms closer to shore (moving left and down in the figure). If water depth is not reduced, then the cost reduction of moving from a location similar to Horns Rev III to a location just $4-5 \mathrm{~km}$ from shore will be only $4 \%$ (just moving left). If conditions regarding water depth like Horns Rev III (approx. 17m) are very scarce, the relevant comparison might be between average water depths of $25 \mathrm{~m}$ versus water depths similar to some DK nearshore sites, of around $15 \mathrm{~m}$. The benefit in this case will be around $\mathbf{1 0 \%}$. The nearshore tender in Denmark resulted in quite low bids for nearshore at Vesterhav Syd and Nord that are equivalent to cost reductions of around 20\% in a time span of about 10 years from Rødsand to Vesterhav development. That the recent offshore bids in Denmark imply lower costs than in the corresponding depth lines in Figure 4, illustrates that cost reductions in time due to general technology development, turbine up-scaling and competitive pressure in the industry are important drivers for cost reductions and this is not captured in the EEA scaling factors nor in the regression example. 


\subsection{Perspectives on willingness to pay for moving turbines further offshore}

To compare the cost advantage of locating wind farms closer to shore in Denmark a hypothetical willingness to pay is combined with the cost advantage of moving turbines further offshore. See (Hevia-Koch, Ladenburg, \& Petrovic, 2018) for an assessment of preferences for siting and implied willingness to pay for offshore locations compared to onshore. For offshore wind costs we use the LCOE from Figure $\mathbf{4}$ and construct the marginal cost of moving $5 \mathrm{~km}$ further out, for example from 10 to $15 \mathrm{~km}$ considering only the effects included in the scaling factors from EEA (Table 3). The marginal cost at $10 \mathrm{~km}$ is around $0.05 \mathrm{c} € / \mathrm{kWh}$ if it is possible to stay at the same depth (depth curves in the bottom). If to the contrary moving $5 \mathrm{~km}$ further out necessitates siting at $25 \mathrm{~m}$ depth rather than $10 \mathrm{~m}$ (orange dotted line) then cost increases with around $0.6 \mathrm{c} € / \mathrm{kWh}$. This illustrates that if depth increase is involved then marginal costs may well exceed the marginal willingness to pay for moving these turbines $5 \mathrm{~km}$ further out.

Any marginal cost level between the top line (orange) and the bottom one (brown) is possible, but the lower part of the range is most likely in Denmark where increasing distance by eg. $4 \mathrm{~km}$ increase depth with 5-10m.

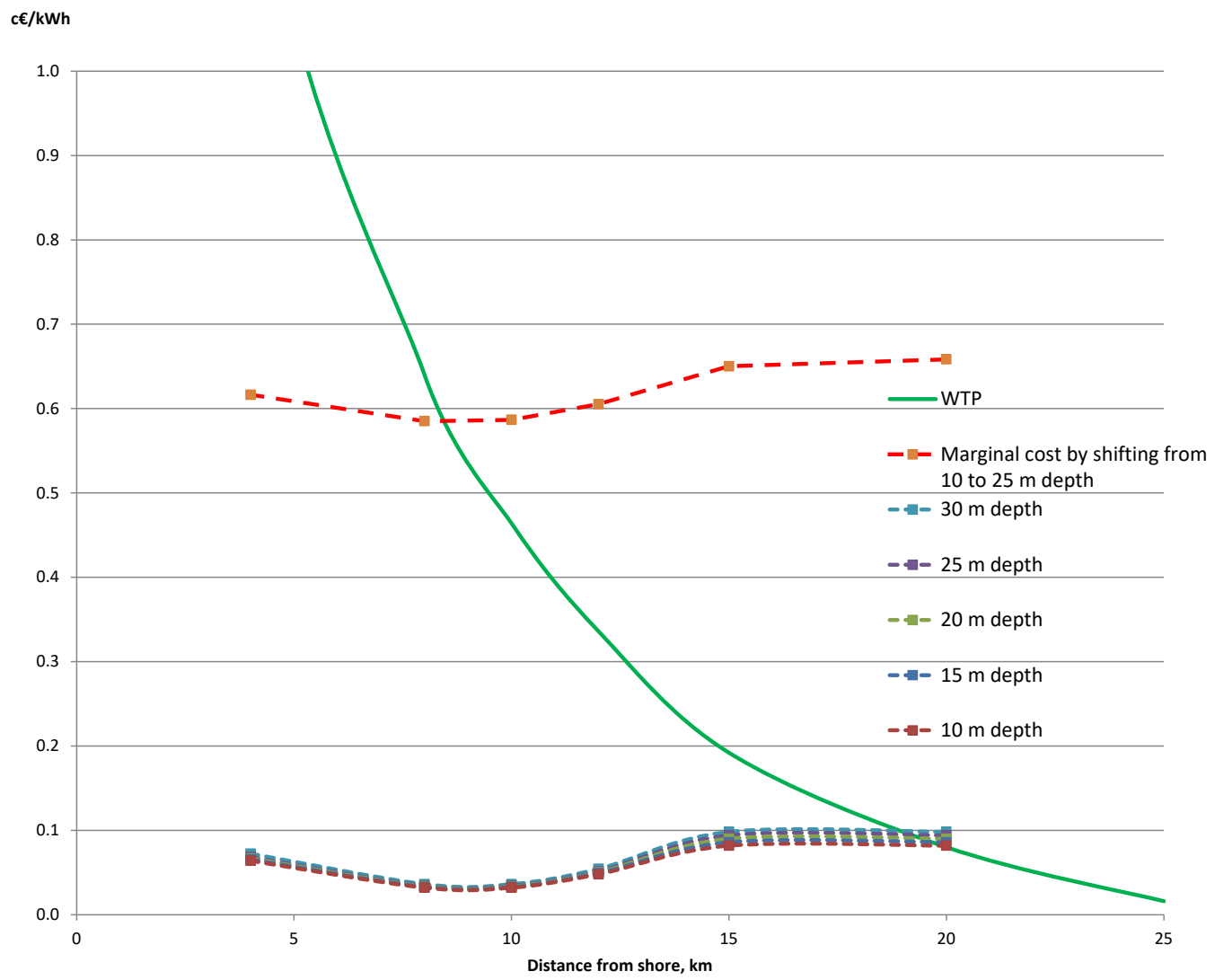

Figure 5 Examples of nearshore marginal costs and willingness to pay for moving turbines further off shore

The range of marginal cost for increasing distance and depth at the same time most representative for Danish conditions is probably $0.2-0.4 \mathrm{c} € / \mathrm{kWh}$ for $4 \mathrm{~km}$ distance and $5 \mathrm{~m}$ depth addition. With the diminishing marginal willingness to pay for distance example assumed there would be a benefit of moving turbines to somewhere between 15 and $20 \mathrm{~km}$ from shore. This exemplifies that the marginal willingness to pay for distance is relevant to consider for the specific sites in consideration for development, but that the actual cost additions (especially depth) implications should be balanced with that. As the marginal willingness to pay for wind is probably extremely site and context specific (Hevia-Koch \& Ladenburg, 2016), (Hevia-Koch et al., 2018) this is just an illustrative example, but others have examined the willingness to pay for the distance and (Krueger, Parsons, \& 
Firestone, 2011) find that there is willingness to pay for moving turbines $20 \mathrm{~km}$ off the cost corresponding with the additional costs of doing so.

\section{Concluding remarks}

The main conclusion is that nearshore potentials in Denmark may not be sufficiently cost attractive to balance the willingness to pay to locate wind farms slightly further away from the coast. This is due to the relatively shallow waters in Denmark allowing wind farms to be developed a bit further from shore without considerably increasing the water depth.

Nearshore wind potentials exist in Denmark, and they have potentially lower costs than further offshore, but the cost advantage is probably lower than in other countries, because offshore costs are comparatively lower in Denmark. The nearshore potentials are smaller, and possible wind farm sizing is also limited for some sites in Denmark. However, there are still potentials with lower costs than further ashore sites. It is difficult to identify one main contribution as e.g. more shallow water as the source of expected lower costs based on a small sample of data examined for Denmark. Significant cost advantages are however only expected if water depth is considerably lower than at more offshore sites.

An illustrative calculation of benefits indicates that cost could be only 4\% lower nearshore if no reduction in water depth is achieved. Compared to this, moving from $25 \mathrm{~km}$ distance at the same time as reducing water depth from $25 \mathrm{~m}$ to $15 \mathrm{~m}$ may provide cost reductions of around $10 \%$. If the marginal willingness to pay (WTP) curve is as illustrated in Figure 5 it would be attractive to shift further offshore development from for example 25-30 km, to around $15 \mathrm{~km}$ from shore provided that depth can be reduced at least 5-10 m. If depth cannot be reduced by such a shift nearshore expansion at less than $15 \mathrm{~km}$ from shore is not socially attractive.

Finally we illustrate that there is a possible trade-off between the additional cost of moving turbines further offshore and the willingness of people to pay for that. As long as further offshore do not imply increased depth the additional cost may be smaller than the willingness to pay, but for other cases increased depth will mean higher costs that can only be matched by willingness to pay for moving from extreme nearshore sites to 8-15 km off the coast. The local site specific cost characteristics and local willingness to pay must be considered in any case and no generalisation can be made even for the relatively small Danish case.

\section{Acknowledgements}

The authors much appreciate funding by Project 1305-00021B under the Danish Council for Strategic Research (Wind 2050). An early version of this work was presented at the 39 $9^{\text {th }}$ IAEE Conference in Bergen 2016.

\section{References}

Auer, H. (2006). THE RELEVANCE OF UNBUNDLING FOR LARGE-SCALE RES-E GRID INTEGRATION IN EUROPE. Energy and Environment, 17(6), 907-928.

Beurskens, L. W. M., \& Hekkenberg, M. (2011). Renewable Energy Projections as Published in the National Renewable Energy Action Plans of the European Member States. qualenergia.it.

Danish Energy Agency. Opdateret tillægsblad om kalkulationsrente, levetid og reference til Vejledning i samfundsøkonomiske analyser på energiområdet [Updated appendix of discounting, lifetime and reference to Instruction in socio-economic analyses in the energy sector] (2013).

Danish Energy Agency. (2015a). Eksisterende havvindmølleparker og aktuelle projekter.

Danish Energy Agency. (2015b). Levelized cost of energy - LCoE calculator: Methodology, assumptions and guidelines.

Danish Energy Agency. (2017). Master data register for DK wind turbines at end of February 2017. Retrieved from https://ens.dk/service/statistik-data-noegletal-og-kort/data-oversigt-over-energisektoren

Danish Energy Agency, \& Energinet.dk. (2013). New Offshore Wind Tenders in Denmark.

DECC (Department of Energy \& Climate Change). (2013). Electricity Generation Costs. https://doi.org/267393///1/1 25 May 2010

EEA. (2009). Europe's onshore and offshore wind energy potential. EEA Technical report (Vol. 6). 
Copenhagen. https://doi.org/10.2800/11373

Energinet.dk, \& Danish Energy Agency. (2017). Technology Data for Energy Plants August 2016: Update June, October and November 2017.

EWEA. (2009). The economics of wind energy. Renewable and Sustainable Energy Reviews (Vol. 13). https://doi.org/10.1016/j.rser.2008.09.004

EWEA. (2015). Balancing responsibility of wind power plants (Vol. 2015).

Fichtner/prognos. (2013). Cost Reduction Potentials of Offshore Wind Power in Germany. Retrieved from http://www.offshore-

stiftung.com/60005/Uploaded/SOW_Download\%7CStudy_LongVersion_CostReductionPotentialsofOffs horeWindPowerinGermany.pdf

Fraunhofer ISE. (2013). Levelized Cost of Electricity Renewable Energy Technology. Retrieved from https://www.ise.fraunhofer.de/en/publications/veroeffentlichungen-pdf-dateien-en/studien-undkonzeptpapiere/study-levelized-cost-of-electricity-renewable-energies.pdf

Gonzalez-Rodriguez, A. G. (2017). Review of offshore wind farm cost components. Energy for Sustainable Development, 37, 10-19. https://doi.org/10.1016/j.esd.2016.12.001

González, J. S., Rodríguez, Á. G. G., Mora, J. C., Burgos Payán, M., \& Santos, J. R. (2011). Overall design optimization of wind farms. Renewable Energy, 36(7), 1973-1982. https://doi.org/10.1016/j.renene.2010.10.034

Heptonstall, P., Gross, R., Greenacre, P., \& Cockerill, T. (2012). The cost of offshore wind: Understanding the past and projecting the future. Energy Policy, 41, 815-821. https://doi.org/10.1016/j.enpol.2011.11.050

Hevia-Koch, P., \& Jacobsen, H. K. (2019). Comparing offshore and onshore wind development considering acceptance costs. Energy Policy, 125, 9-19. https://doi.org/10.1016/j.enpol.2018.10.019

Hevia-Koch, P., \& Ladenburg, J. (2016). Estimating Preferences for Wind Turbine Locations - A Critical Review of Visualisation Approaches. SSRN Electronic Journal. https://doi.org/10.2139/ssrn.2848529

Hevia-Koch, P., Ladenburg, J., \& Petrovic, S. (2018). Preferences for Offshore-Onshore Wind Power Development in Denmark- Accounting for Spatial Data (USAEE Working Paper Series No. 18-330). SSRN Electronic Journal. Retrieved from https://papers.ssrn.com/sol3/papers.cfm?abstract_id=3121495

International Renewable Energy Agency. (2012). Wind Power Cost Analysis (Vol. 1).

IRENA. (2012). Renewable Energy Technologies: Cost Analysis Series Wind Power (Vol. 1). Retrieved from https://www.irena.org/documentdownloads/publications/re_technologies_cost_analysis-wind_power.pdf

Joskow, P. L. (2011). Comparing the costs of intermittent and dispatchable electricity generating technologies. American Economic Review, 101(3), 238-241. https://doi.org/10.1257/aer.101.3.238

Kitzing, L., \& Morthorst, P.-E. (2015). Trends in offshore wind economics - the past and the future. Proceedings - 14th Wind Integration Workshop.

Klinge Jacobsen, H., \& Schroder, S. T. (2012). Curtailment of renewable generation: Economic optimality and incentives. Energy Policy, 49(2012), 663-675. https://doi.org/10.1016/j.enpol.2012.07.004

Krueger, A., Parsons, G., \& Firestone, J. (2011). Valuing the visual disamenity of offshore wind power projects at varying distances from the shore: An application on the Delaware shoreline. Land Economics, 87(2), 268-283. Retrieved from http://le.uwpress.org/content/87/2/268.short

Millborrow, D. (2016, January). Global costs analysis -- the year offshore wind costs fell. Wind Power Monthly. Retrieved from http://www.windpowermonthly.com/article/1380738/global-costs-analysis-year-offshorewind-costs-fell

Mone, C., Hand, M., Maples, B., \& Smith, A. (2015). 2013 Cost of Wind Energy Review. Golden, CO. Retrieved from http://www.nrel.gov/docs/fy15osti/63267.pdf

Morthorst, P. E., \& Kitzing, L. (2016). Economics of building and operating offshore wind farms. In Offshore wind farms: Technologies, Design and Operation (pp. 9-28). Woodhead Publishing Series in Energy. 
Mytilinou, V., Kolios, A. J., \& Lorenzo, G. Di. (2017). A comparative multi-disciplinary policy review in wind energy developments in Europe. International Journal of Sustainable Energy, 36(8), 754-774. https://doi.org/10.1080/14786451.2015.1100194

Prässler, T., \& Schaechtele, J. (2012). Comparison of the financial attractiveness among prospective offshore wind parks in selected European countries. Energy Policy, 45, 86-101. https://doi.org/10.1016/j.enpol.2012.01.062

The Crown Estate. (2012). Offshore Wind Cost Reduction Pathways Study. Retrieved from http://www.thecrownestate.co.uk/media/5493/ei-offshore-wind-cost-reduction-pathways-study.pdf

TKI Wind op Zee. (2015). TKI Wind op Zee Cost reduction options for Offshore wind in the Netherlands FID 2010-2020. Retrieved from http://www.tki-windopzee.nl/files/2015-10/151028-tki-offshore-wind-costreduction-final-stc.pdf

Van der Zwaan, B., Rivera-Tinoco, R., Lensink, S., \& van den Oosterkamp, P. (2012). Cost reductions for offshore wind power: Exploring the balance between scaling, learning and R\&D. Renewable Energy, 41, 389-393. https://doi.org/10.1016/j.renene.2011.11.014

Visser, E., \& Held, A. (2014). Methodologies for estimating Levelised Cost of Electricity (LCOE).

Voormolen, J. A., Junginger, H. M., \& van Sark, W. G. J. H. M. (2015). Unravelling historical cost developments of offshore wind energy in Europe. Energy Policy, 88, 435-444. https://doi.org/10.1016/j.enpol.2015.10.047

Wiser, R., Jenni, K., Seel, J., Baker, E., Hand, M., Lantz, E., \& Smith, A. (2016a). Expert elicitation survey on future wind energy costs. Nature Energy, 1(10), 16135. https://doi.org/10.1038/nenergy.2016.135

Wiser, R., Jenni, K., Seel, J., Baker, E., Hand, M., Lantz, E., \& Smith, A. (2016b). Forecasting Wind Energy Costs \& Cost Drivers: The Views of the World's Leading Experts. IEA Wind Task 26. Retrieved from https://emp.lbl.gov/sites/default/files/lbnl-1005717.pdf

Wiser, R., Yang, Z., Hand, M., Hohmeyer, O., Infield, D., Jensen, P. H., ... Zervos, A. (2011). Wind Energy. IPCC Special Report on Renewable Energy Sources and Climate Change Mitigation, 535-608. 


\section{Appendix A: Regression of depth and distance}

\begin{tabular}{|l|c|c|c|c|}
\hline $\begin{array}{l}\text { Regression on LCOE } \\
\text { with depth and distance }\end{array}$ & Estimate & Std. Error & t value & $\operatorname{Pr}(>|\mathrm{t}|)$ \\
\hline Intercept & 46.5945 & 9.8109 & 4.749 & 0.0008 \\
\hline Depth & 2.9624 & 0.7152 & 4.142 & 0.0020 \\
\hline Distance & 0.0766 & 0.4617 & 0.166 & 0.8715 \\
\hline $\begin{array}{l}\text { Regression on LCOE } \\
\text { with depth only }\end{array}$ & Estimate & Std. Error & $\mathrm{t}$ value & $\operatorname{Pr}(>|\mathrm{t}|)$ \\
\hline Intercept & 47.1235 & 8.8592 & 5.319 & 0.0002 \\
\hline Depth & 2.9889 & 0.6656 & 4.491 & 0.0009 \\
\hline
\end{tabular}

Table 4 Results for regression with depth and distance from shore for Danish offshore wind farms

Distance to shore fails to be significant even at the $10 \%$ level. While there is definitively correlation between the two variables in general this effect seems less critical in the Danish data. The variation in distance from shore is limited in the Danish data (not exceeding $30 \mathrm{~km}$ ) and a larger variation in this variable for an international sample of wind farms may produce different results. 